\title{
PERAN ICRC DALAM PERKEMBANGAN HUKUM HUMANITER INTERNASIONAL DI ERA GLOBAL
}

\author{
J oko Setiyono \\ Fakultas Hukum Universitas Diponegoro \\ jokosetiyon061@yahoo.com
}

\begin{abstract}
ABSTRAK
ICRC adalah salah satu organisasi internasional tertua yang ada di dunia. Selama berdiri hingga saat ini ICRC telah mengalami banyak hambatan, namun pada kenyataannya eksistensi ICRC sebagai organisasi internasional hingga saat ini tetap tidak terbantahkan. Bukan hanya eksis dalam menjalankan visi misinya selama ini, tetapi ICRC juga turut memberikan kontribusi terhadap perkembangan Hukum Humaniter Internasional. Hasil penelitian menunjukkan bahwa pada perkembangannya ICRC sebagai subyek Hukum Internasional memiliki eksistensi yang tidak terbantahkan. Hal ini setidaknya dipengaruhi oleh 3 hal pokok, yakni selama masih ada perang, eksistensi ICRC akan selalu terjaga; belum ada organisasi lain yg menjadi competitor; dan peran ICRC yang telah diakui oleh masyarakat internasional selama bertahun-tahun. Salah satu peran tersebut adalah pada bidang perkembangan Hukum Humaniter Internasional. ICRC berperan untuk memantau perubahan sifat konflik bersenjata, termasuk diantaranya adalah mengatur konsultasi dengan maksud untuk memastikan kemungkinan mencapai kesepakatan tentang aturan baru dan mempersiapkan rancangan teks untuk diserahkan kepada konferensi diplomatik. ICRC juga telah menyusun sebuah laporan tentang aturan-aturan Hukum Humaniter Internasional yang berasal dari Hukum Kebiasaan dan dapat berlaku dalam konflik bersenjata internasional maupun non internasional.
\end{abstract}

Kata Kunci : ICRC, Eksistensi, Hukum Humaniter Internasional

I. Pendahuluan

International Committe of The Red Cross (ICRC) atau yang dikenal sebagai Komite Internasional Palang Merah adalah merupakan suatu lembaga kemanusiaan yang bersifat internasional yang bermarkas besar di Jenewa, Swiss. Negara-negara peserta yang merupakan penanda tangan dari keempat buah Konvensi Jenewa tahun 1949 dan kedua buah Protokol Tambahan tahun 1977, telah bersepakat untuk memberikan mandat kepada ICRC guna memberikan perlindungan terhadap para korban konflik bersenjata, baik yang bersifat internasional maupun non internasional, yang meliputi korban 
Jurnal Law Reform

Volume 13, Nomor 2, Tahun 2017
Program Studi Magister IImu Hukum Fakultas Hukum Universitas Diponegoro luka dalam peperangan, tawanan perang, para pengungsi, warga sipil, dan non kombatan lainnya.

Selain itu patut untuk dikemukakan pula bahwa International Committe of The Red Cross (ICRC) juga merupakan salah satu dari tiga komponen, sekaligus cikal bakal bagi Gerakan Palang Merah dan Bulan Sabit Merah Internasional, termasuk pula didalamnya Federasi Internasional Palang Merah dan Bulan Sabit Merah (IFRC) dan 186 Perhimpunan Nasional, yang mana Perhimpunan Nasional di Indonesia bernama Palang Merah Indonesia (PMI). ICRC merupakan organisasi internasional di bidang kemanusiaan tertua dan dihormati dalam gerakan dan merupakan salah satu organisasi yang paling banyak diakui di seluruh dunia. Salah satu contoh pengakuan dunia, ICRC telah tiga kali menerima Hadiah Nobel Perdamaian pada tahun 1917, 1944, dan 1963. ICRC merupakan organisasi yang tidak memihak, bersifat netral, dan mandiri, yang misinya sematamata bersifat kemanusiaan, yaitu untuk melindungi kehidupan dan martabat para korban konflik bersenjata dan situasi-situasi kekerasan lain dan memberi mereka bantuan. ICRC mengarahkan dan mengkoordinasi kegiatan bantuan kemanusiaan dan berupaya mempromosikan dan memperkuat Hukum Humaniter Internasional dan prinsip-prinsip kemanusiaan yang bersifat universal. Adapun tugas utama dari ICRC yang bersumber pada Konvensi Jenewa dan Statuta Gerakan, antara lain memantau kepatuhan para pihak yang bertikai kepada Konvensi Jenewa; mengorganisir perawatan terhadap korban luka di medan perang; mengawasi perlakuan terhadap tawanan perang (prisoners of war) dan melakukan intervensi yang bersifat konfidensial dengan pihak berwenang yang melakukan penahanan; membantu pencarian orang hilang dalam konflik bersenjata (layanan pencarian); dan mengorganisir perlindungan dan perawatan penduduk sipil bertindak sebagai perantara netral antara para pihak yang berperang.

ICRC yang didirikan pada tahun 1863 merupakan sebuah organisasi internasional non pemerintah yang bergerak di bidang kemanusiaan. Organisasi ini memiliki prinsip tidak memihak, netral, dan mandiri yang memfokuskan misinya hanya pada aspek kemanusiaan yang dimaksudkan untuk melindungi kehidupan dan martabat korban konflik bersenjata dan korban kekerasan serta memberikan bantuan pada korban-korban tersebut. ICRC berkomitmen siap dalam merespon dan tanggap terhadap kebutuhan bantuan kemanusiaan, seperti halnya yang kini terjadi di Suriah. Tidak mudah untuk melaksanakan bantuan kemanusiaan terlebih lagi konflik Suriah ini dapat dikatakan sebagai tragedi kemanusiaan berkepanjangan, namun berdasarkan Hukum Humaniter Internasional, pihak-pihak yang terlibat di dalam konflik harus mengizinkan dan memberikan jalur evakuasi cepat dan tanpa 
Jurnal Law Reform

Volume 13, Nomor 2, Tahun 2017
Program Studi Magister IImu Hukum Fakultas Hukum Universitas Diponegoro hambatan bagi akses bantuan kemanusiaan, dan untuk saling menghormati hak orang-orang yang sakit dan terluka serta pelarangan keras penggunaan senjata kimia di dalam konflik.

ICRC merupakan lembaga independent yang bergerak di bidang kemanusiaan yang selalu berusaha memberikan perlindungan dan bantuan kepada para korban, baik dalam pertikaian bersenjata internasional maupun dalam konflik internal. Secara garis besar ICRC adalah pendiri dan anggota Palang Merah Internasional, inisiator pertama dalam penyusunan International Humanitarian Law, pendukung dalam penyebarluasannya serta pengawas penerapan International Humanitarian Law dan prinsip Palang Merah dan penyelanggara operasi kemanusiaan berdasarkan permintaan suatu negara atau inisiatif sendiri. ICRC tetap melaksanakan misi aslinya, yaitu memberikan perlindungan serta bantuan kepada rakyat sipil dan militer yang menjadi korban dalam pertikaian senjata internasional, kekacauan dan ketegangan dalam negeri di seluruh dunia. Bilamana dibutuhkan, ICRC mengorganisir program bantuan kemanusiaan dan operasi medis bagi korban perang, penduduk sipil di bawah pendudukan musuh, serta pengungsi.

ICRC juga ikut andil menyediakan program koordinasi, tentang arah strategis dan dukungan finansial untuk melindungi warga sipil dan hak-hak mereka, termasuk inisiatif untuk memastikan bahwa perawatan dan perlindungan yang diberikan sesuai dengan program Disarmament, Demobilization, and Reintegration (DDR). Perlindungan keamanan kemanusiaan dalam situasi konflik merupakan salah satu problematika yang membutuhkan penyelesaian melalui beberapa tahapan. Salah satunya yakni menciptakan keamanan negara. Menurut Barry Buzan keamanan negara merupakan salah satu kondisi penting bagi keamanan manusia, karena tanpa adanya negara, maka tidaklah terlampau jelas agen-agen/lembaga manakah yang dapat bertindak atas nama individu.

Dalam penanggulangan krisis kemanusiaan khususnya anak-anak korban perang, ICRC didukung UNICEF dan TRC dan pemerintah setempat untuk membantu memberikan pertolongan terhadap anak-anak korban perang. Dengan melakukan kerjasama organisasi non pemerintah setempat, UNICEF, ICRC mengembangkan konsep rehabilitasi bagi anakanak korban konflik yang dinamakan psycho social programs yang berisikan teknik-teknik terapi untuk para tentara anak. Batas maksimum seorang anak dalam pusat rehabilitasi adalah enam bulan, kecuali anak-anak yang masih membutuhkan perawatan medis dan anggota keluarga mereka belum ditemukan.

Selama berdiri hingga saat ini tentu ICRC telah mengalami banyak hambatan, namun pada kenyataannya eksistensi ICRC sebagai organisasi 
internasional hingga saat ini tetap tidak III. Hasil dan Pembahasan terbantahkan. Bukan hanya eksis dalam A. Eksistensi ICRC di Era Global

menjalankan visi misinya selama ini, tetapi ICRC juga turut memberikan kontribusi terhadap perkembangan Hukum Humaniter Internasional. Berdasarkan latar belakang tersebut, penulis merasa perlu mengangkatnya menjadi sebuah penelitian yang berfokus pada bidang Hukum Humaniter Internasional, dimana titik bidik permasalahan yang diangkat adalah :

1. Mengapa hingga saat ini ICRC tetap eksis sebagai organisasi kemanusiaan yang bersifat internasional ?

2. Bagaimanakah peran ICRC bagi perkembangan Hukum Humaniter Internasional hingga dewasa ini ?

\section{Metode Penelitian}

Penelitian ini disusun menggunakan pisau pendekatan yuridis-normatif dengan spesifikasi penelitian yang bersifat deskriptif analitis. Jenis datanya berupa data sekunder, yang terdiri atas bahan hukum primer, sekunder, dan tersier. Teknik pengumpulan data adalah studi kepustakaan atau dokumentasi. Metode analisis data yang dipergunakan adalah analisis data kualitatif kemudian disimpulkan menggunakan logika deduksi.
Eksistensi dan peran dari organisasi internasional saat ini menjadi begitu penting dalam dunia internasional. Salah satu organisasi internasional yang perannya tidak bisa dikesampingkan hingga saat ini adalah ICRC. Didirikan pada tahun 1863, ICRC merupakan cikal bakal dari Konvensi-konvensi Jenewa dan Gerakan Palang Merah dan Bulan Sabit Merah Internasional. ICRC mengatur dan mengkoordinasi aksi kemanusiaan internasional yang dilakukan oleh Gerakan dalam konflik-konflik bersenjata dan situasi-situasi kekerasan lainnya.

\section{1) ICRC sebagai Subjek Hukum Internasional}

Organisasi internasional adalah organisasi yang timbul dari hubungan internasional yang menampung kehendak banyak negara. Negara melalui organisasi itu akan berusaha mencapai tujuan yang menjadi kepentingan bersama dan kepentingan ini menyangkut bidang kehidupan internasional yang sangat luas sehingga diperlukan peraturan internasional agar kepentingan masingmasing negara dapat terjamin.

Sebagai salah satu organisasi internasional tertua di dunia, ICRC juga merupakan subjek Hukum Internasional. Dalam perkembangan Hukum Internasional selanjutnya, ternyata jenis-jenis subyek Hukum Internasional bertambah sejalan dengan perkembangan hubungan internasional. 
Jurnal Law Reform

Volume 13, Nomor 2, Tahun 2017
Program Studi Magister Ilmu Hukum Fakultas Hukum Universitas Diponegoro
Jenis-jenis subyek Hukum Internasional yang telah diakui secara umum sampai saat ini adalah Negara, Organisasi Internasional, ICRC, Tahta Suci Vatikan, Individu, dan Belligerency. Subyek Hukum Internasional merupakan entitas yang menyandang hak-hak dan kewajiban-kewajiban internasional, dan mempunyai kemampuan untuk mempertahankan hak-haknya dengan mengajukan klaim-klaim internasional. Sedangkan menurut Mochtar Kusumaatmadja pengertian subyek Hukum Internasional adalah :1

a. Pemegang (segala) hak dan kewajiban menurut Hukum Internasional. Subyek hukum semacam ini disebut subyek Hukum Internasional penuh, misalnya negara.

b. Mencakup pula keadaan-keadaan dimana yang dimilikinya itu hanya hak-hak dan kewajibankewajiban terbatas, misalnya kewenangan untuk mengadakan penuntutan hak yang diberikan oleh Hukum Internasional di muka pengadilan berdasarkan suatu konvensi, misalnya individu.

c. Subyek Hukum Internasional memperoleh kedudukan berdasarkan Hukum Kebiasaan Internasional karena perkembangan sejarah Mochtar Kusumaatmadja dalam pembahasan mengenai subyek Hukum Internasional

${ }^{1}$ Mocthar Kusumaatmadja dan Etty R. Agoes, Pengantar Hukum Internasional, Jakarta, 1997, halaman halaman 8 memberikan tempat yang terpisah dari organisasi internasional bagi ICRC. Beliau juga menyebutkan bahwa sekarang Palang Merah Internasional (ICRC) secara umum diakui sebagai organisasi internasional yang memiliki kedudukan sebagai subyek Hukum Internasional walaupun dengan ruang lingkup yang terbatas. ${ }^{2}$ Dimensi internasional ICRC dikuatkan dengan Headquarter Agreement atau Seat Agreement yang telah dibuat 50 negara dimana ICRC membuka kantor perwakilan (misalnya regional delegation). Dengan adanya perjanjian ini, negara mengakui ICRC sebagai suatu kesatuan hukum dan menjamin hak-hak istimewa serta kekebalannya seperti anggota korps diplomatik. Hal ini termasuk kekebalan dari proses hukum, yang melindungi staf ICRC dari proses administrasi dan yudisial, serta tidak mengganggu arsip dan dokumen ICRC. ${ }^{3}$

Dasar hukum mengenasi status ICRC terdapat dalam Pasal 5 (1) Statuta Gerakan Palang Merah dan Bulan Sabit Merah, yang menyebutkan bahwa :

The International Committee, founded in Geneva in 1863 and formally recognized in Geneva Conventions and by International Conferences of The Red Cross, is an independent humanitarian organization having a

2lbid, halaman 94.

${ }^{3}$ Anonim, ICRC Answes To Your Questions, Geneva, 1996, halaman 9. 
Jurnal Law Reform

Volume 13, Nomor 2, Tahun 2017
Program Studi Magister Ilmu Hukum Fakultas Hukum Universitas Diponegoro status of its own. It co-opts its members from among Swiss citizens

Keanggotaan ICRC sendiri memang bukanlah terdiri dari negara-negara, tetapi sifat internasional ICRC sebagi sebuah organisasi tidaklah dilihat dari keanggotaannya, tetapi dari misi dan wilayah kerjanya yang berada hampir di seluruh dunia. Hilaire Mc. Coubrey memberikan penegasan bahwa "ICRC is being 'international' in function rather than in membership or corporate identity"4. Oleh karena itu, hingga detik ini ICRC diakui sebagai salah satu organisasi internasional yang menjadi subjek Hukum Internasional.

\section{2) Globalisasi, Perang, dan ICRC}

Globalisasi terus berjalan dengan cepat. Globalisasi merupakan sebuah konsepsi yang menggambarkan bahwa saat ini dunia terintegrasi secara politik dan ekonomi. Globalisasi bukanlah sebuah hal yang secara alami terjadi (natural), namun merupakan sebuah proses yang terjadi secara sadar karena dirancang dengan terencana oleh manusia. Secara umum globalisasi merupakan sebuah proses dimana mengglobalnya atau mendunianya "sesuatu" yang melintasi batas-batas negara, dimana "sesuatu" disini diartikan sebagai ide, barang dan jasa maupun aktor-aktor yang lain dalam hubungan internasional.

${ }^{4}$ Hilaire Mc. Coubrey, International Humanitarian Law : The Regulation of Armed Conflicts, 1994, halaman 32.
Globalisasi juga telah membawa ilmu pengetahuan dan teknologi berkembang menjadi begitu signifikan, tetapi pada kenyataannya kemajuan tersebut belum mampu membawa kedamaian di dunia. Francis Fukuyama dalam artikelnya "The End of History" menyatakan bahwa pasca perang dingin, dunia akan jauh lebih damai karena konflik dan perang akan menurun secara substansial, karena menurutnya penyebab perang antar negara selama ini adalah karena perbedaan ideologi. Namun, fakta di lapangan justru berkata lain, di era global peperangan tetap terjadi. Fenomena Arab Spring sebagai salah satu bentuk menyebarnya paham demokrasi di dunia telah menyulut kekacauan di beberapa negara Timur Tengah. Kejahatan terorisme juga kian mengglobal karena berhasil memanfaatkan kemajuan iptek yang terjadi di era global. Setidaknya hingga detik ini masih ada beberapa konflik terkait masalah keamanan (baik itu terorisme, perang saudara, atau perang antar negara) yang terjadi dan memakan korban dalam jumlah besar.

a) Konflik Israel Palestina

Warga sipil Palestina terus menjadi subjek yang kehidupan, keselamatan fisik, dan kebebasannya terancam dan di tahun 2014 menyaksikan "kematian warga sipil tertinggi sejak 1967". Menurut laporan Kantor PBB untuk Koordinasi Urusan Kemanusiaan (Office for the Coordination of Humanitarian Affairs/OCHA), Israel 
Jurnal Law Reform

Volume 13, Nomor 2, Tahun 2017
Program Studi Magister Ilmu Hukum Fakultas Hukum Universitas Diponegoro merebut Tepi Barat, Jalur Gaza dan wilayah Arab di Yerusalem Timur dalam perang tahun 1967 dan secara sepihak mencaplok Jerusalem Timur segera setelahnya. Selama tahun 2014, menurut OCHA, Israel dan Hamas bertempur dalam peperangan dahsyat di Gaza yang membunuh hampir 2.200 orang, sementara kekerasan intens di Jerusalem Timur dan Tepi Barat membunuh puluhan warga Palestina dan hanya beberapa warga Israel. Laporan OCHA yang berjudul "Fragmented Lives" juga menyebutkan bahwa di Jalur Gaza, 1,8 juta warga Palestina menghadapi peningkatan permusuhan paling buruk sejak 1967 dengan lebih dari 1.500 warga sipil terbunuh, lebih dari 11.000 orang terluka dan 100.000 orang terlantar. Dalam laporannya, lembaga itu juga menyebutkan bahwa 550 anak termasuk diantara korban tewas dalam peperangan itu. Sementara di Tepi Barat dan Jerusalem, 58 warga Palestina terbunuh, kebanyakan dalam bentrokan dengan pasukan Israel, dan lebih dari 6.000 orang terluka. OCHA menyebutkan bahwa 1.215 warga Palestina terlantar akibat perusakan rumah dan bertentangan dengan Hukum Humaniter Internasional yang merupakan bagian dari Hukum Internasional, aktivitas permukiman dan pemukim tetap berjalan sehingga membuat komunitas Palestina jadi rentan. Di pihak Israel, 5 korban sipil, termasuk seorang anak, juga 1 petugas keamanan terbunuh. Laporan itu juga menyebutkan bahwa korban tewas di pihak
Israel sebanyak 73 orang dan kebanyakan tentara. Serangan Palestina ke Israel, juga telah menyebabkan 12 orang tewas. Komunitas internasional mendesak Israel menghentikan pembangunan permukiman Yahudi di wilayah Palestina yang diduduki karena melihatnya sebagai kendala menuju perdamaian.

b) Perang melawan ISIS di Syria

ISIS telah mengeksekusi sekitar 3.027 orang di Suriah dalam tempo setahun. Dari jumlah itu, sebanyak 1.787 korban di antaranya warga sipil. Data korban eksekusi Kelompok Negara Islam Irak dan Suriah (ISIS) itu dipaparkan pemantau krisis Suriah. Menurut Observatorium Suriah untuk Hak Asasi Manusia, ISIS mulai mengeksekusi orangorang di Suriah sejak 29 Juni 2014 atau setahun silam. Dari 1.787 korban warga sipil yang dieksekusi ISIS, 74 diantaranya adalah anak-anak, demikian pernyataan Observatorium, seperti dikutip Al Arabiya. Hampir setengah dari total korban eksekusi ISIS adalah anggota suku Shaitat, sebuah suku Sunni yang melawan ISIS. Menurut Observatorium, total korban eksekusi ISIS itu juga termasuk 223 orang yang dieksekusi di wilayah Kobane, dekat perbatasan Turki, pada pekan Ialu. Tak hanya warga sipil dan musuh-musuh ISIS, sebanyak 143 anggota ISIS juga dieksekusi kelompok itu atas tuduhan mencoba berkhianat. ISIS muncul di Suriah pada tahun 2013. Kelompok ini muncul dari sempalan Al Qaeda di Irak yang 
Jurnal Law Reform

Volume 13, Nomor 2, Tahun 2017
Program Studi Magister IImu Hukum Fakultas Hukum Universitas Diponegoro

semula berafiliasi dengan kelompok Al Nusra. terluka, terkena dampak gempuran pesawatKetika Al Nusra menolak bergabung, kedua pesawat tempur Koalisi Teluk yang dipimpin Arab kelompok menjadi saingan. ISIS kemudian Saudi. Data itu disampaikan Rupert Colville, juru mengumumkan berdirinya "Khilafah" di wilayah di Suriah dan Irak, dengan memproklamirkan Abu Bakr Al Baghdadi sebagai "Khalifah" dengan sebutan "Khalifah Ibrahim". Sementara itu, menurut Observatorium, Amerika Serikat dan koalisi internasional yang memerangi ISIS sudah menewaskan sekitar 8 ribu militan kelompok radikal itu melalui serangan udara.

c) Perang melawan Boko Haram di Afrika

Amnesti Internasional menyatakan, setidaknya 1.600 orang terbunuh dalam konflik Boko Haram sejak Juni, membuat total korban dari masyarakat sipil mencapai 3.500 orang pada tahun 2014. Kematian di Nigeria, Kamerun, Chad, dan Niger timbul karena serangan militer melawan kelompok militan Islam. Jumlah orang yang terbunuh sejauh ini sangat mengejutkan dengan lebih dari 3.500 korban jiwa berasal dari warga sipil selama kurang dari 300 hari, sebagaimana dikemukakan Netsanet Belay selaku Direktur Penelitian dan Advokasi Afrika Amnesti Internasional.

d) Perang Saudara di Yaman

PBB menyatakan, lebih dari 550 warga sipil, termasuk 115 anak-anak, telah tewas akibat perang di Yaman. Sedangkan total korban tewas dalam perang di Yaman itu sudah mencapai 1.080 orang. Data PBB yang dilansir, menyebut 1.185 orang bicara Komisaris Tinggi PBB untuk Hak Asasi Manusia, seperti dilansir Al Arabiya tanggal 25 April 2015. Menurutnya, data korban tewas dari kalangan rakyat sipil itu merupakan data sejak konflik pada 26 Maret hingga 22 April 2015. Sementara itu, juru bicara operasi militer Koalisi Teluk, Brigadir Jenderal Ahmed Asseri, kembali menuding milisi Houthi sengaja bersembunyi di daerah pemukiman sipil. Menurutnya, kelompok pemberontak Yaman itu sengaja menjadikan warga yang tidak bersalah sebagai tameng. Sedangkan Amnesty International dalam laporan terbarunya menyoroti dampak serangan udara dan empat kota lainnya di Yaman, sebagai bentuk ketidakpatuhan terhadap Hukum Internasional. Serangan udara yang dimulai 26 Maret telah mengubah banyak wilayah di Yaman menjadi tempat yang berbahaya bagi warga sipil.

e) Perang Saudara di Ukraina

Korban tewas dalam perang saudara di Ukraina sejak Apri 2014 hingga 2015 telah mencapai lebih dari 6.000 orang, seperti disampaikan oleh badan HAM PBB dalam pernyataannya. Pertempuran di Ukraina telah memicu tragedi kemanusiaan bagi warga sipil di negara itu. Banyak warga sipil terjebak di wilayah konflik, terpaksa berlindung di ruang bawah tanah tanpa air, makanan, pemanas, 
Jurnal Law Reform

Volume 13, Nomor 2, Tahun 2017
Program Studi Magister IImu Hukum Fakultas Hukum Universitas Diponegoro listrik dan peralatan medis. Banyak orang yang bertahan karena takut nyawanya terancam jika bergerak. Banyak yang bertahan untuk melindungi anak-anak dan anggota keluarga lainnya, atau barang berharga mereka.

Beberapa peristiwa di atas adalah contoh bagaimana perang hingga saat ini belum berakhir, baik itu perang antar negara, melawan teroris, atau bahkan perang saudara. Pada posisi ini ICRC sebagai organisasi khusus masih memiliki peran krusial dalam hal perlindungan terhadap korban perang. ICRC juga masih harus bekerja keras untuk memaksa para pihak yang bertikai memperhatikan keberlakuan Hukum Humaniter Internasional sebagai batasan mereka dalam melakukan tindakan-tindakan perang ataupun konflik bersenjata internasional maupun non internasional.

\section{3) Hal-Hal Pokok Yang Mempengaruhi Eksistensi ICRC Di Era Global}

Pada perkembangannya ICRC eksistensi dari ICRC bisa dibilang masih tidak tergantikan. Hal ini setidaknya dipengaruhi oleh 3 hal pokok yang menurut penulis memiliki pengaruh dalam eksistensi ICRC, yaitu :

1. Selama masih ada perang, eksistensi ICRC akan selalu terjaga

Globalisasi yang kini tengah berjalan memang membawa kemajuan pesat pada aspek ilmu pengetahuan dan teknologi, tetapi hal itu tidak menghalangi terjadinya perang atau pun konflik bersenjata internasional maupun non internasional. Komunikasi yang lebih mudah berjalan di era global nyatanya masih sulit untuk menghasilkan kesepakatan perdamaian. Perang yang sudah ada dari ribuan tahun yang lalu, dengan kemajuan teknologi yang ada justru menciptakan beragam senjata baru yang lebih efektif dan berbahaya. Akibatnya dari perang ini tentu telah banyak jatuh korban baik dari pihak sipil maupun dari pihak militer.

Beberapa perang yang terjadi hingga saat ini, seperti perang antara Israel-Palestina, Perang Yaman, Perang melawan terorisme internasional seperti ISIS dan Boko Haram, masih terus berjalan dan korban masih tetap berjatuhan. Akibatnya dibutuhkan suatu lembaga netral yang menangani masalah kemanusiaan. ICRC memiliki peran yang besar dalam upaya memberikan bantuan dan pertolongan bagi korban konflik bersenjata, baik yang terjadi di dalam wilayah suatu negara maupun antar negara. Hal tersebut dibuktikan pula dengan diberikannya mandat oleh masyarakat internasional kepada ICRC untuk menjalankan fungsi dan peran dalam membantu bidang kemanusiaan di wilayah konflik.

Pada intinya, selama masih ada perang, maka ICRC akan tetap eksis untuk menjalankan fungsi dan perannya. Kewenangan ICRC dalam menjalankan fungsi dan peranannya dalam memberikan bantuan kemanusiaan menurut Hukum 
Jurnal Law Reform

Volume 13, Nomor 2, Tahun 2017
Program Studi Magister Ilmu Hukum Fakultas Hukum Universitas Diponegoro
Humaniter Internasional telah tercantum dalam Pasal 3 dan Pasal 10 Konvensi Jenewa I tahun 1949 dan Pasal 30 dan Pasal 60 Konvensi Jenewa tahun IV 1949, asas-asas Hukum Humaniter Internasional, Statuta Gerakan Palang Merah dan Bulan Sabit Merah Internasional, dan dua buah Protokol Tambahannya tahun 1977, yang proses perumusannya didukung secara aktif oleh ICRC.

Implementasi peran ICRC dalam situasi konflik tertera dalam Pasal 5 Statuta Gerakan No. 3, 4, dan 7 yang dapat bertindak sesuai dengan mandat masyarakat internasional. ICRC juga terus berupaya meningkatkan perlindungan bagi para korban perang seperti di Suriah dengan cara mendorong negara-negara untuk menyusun dan mengadopsi standar-standar hukum yang baru. Berdasarkan mandat masyarakat internasional ICRC memberikan bantuan seperti kelembagaan sistem untuk warga sipil, meningkatkan pemahaman terhadap Hukum Humaniter Internasional, kunjungan tahanan, tracing, mailing, medis, makanan, dukungan ekonomi, bantuan kelangsungan hidup, dan rehabilitasi ekonomi. Apabila ICRC melihat adanya pelanggaran, maka ICRC akan mengadakan pendekatan kepada pihak yang bertanggung jawab atas peristiwa tersebut dan negara tidak menghalangi aktifitas ICRC dalam memberikan bantuan dalam menjalankan misinya sebagai organisasi kemanusiaan.
2. Belum ada organisasi lain yg menjadi competitor

Hingga saat ini belum ada organisasi internasional yang diakui oleh masyarakat internasional untuk menjalankan fungsi layaknya ICRC. Itu artinya, ICRC menjadi satu-satunya organisasi internasional, yang diakui sebagai subjek Hukum Internasional, dan karena menjadi satu-satunya organisasi, maka peran yang dijalankan oleh organisasi ini benar-benar dirasakan oleh masyarakat internasional. Peran dari ICRC dapat dilihat dalam Pasal 4 ayat (1) dan (2) Statuta ICRC antara lain sebagai lembaga penengah netral, sebagai pelindung dan pelaksana Konvensi-Konvensi Jenewa, betanggung jawab atas penyebarluasan Hukum Humaniter Internasional pada umumnya dan Konvensi Jenewa serta Protokol Tambahannya 1977 pada khususnya.

Setidaknya ada dua manfaat yang dirasakan oleh negara konflik terhadap kehadiran ICRC di wilayahnya. Pertama, manfaat perdamaian dan keamanan internasional, yakni untuk menunjang upaya pemeliharaan dan pemulihan perdamaian, keamanan dan stabilitas internasional. Kedua, manfaat kemanusiaan, yakni untuk menunjang upaya pencegahan dan penanggulangan setiap bentuk bencana serta rehabilitasi akibat-akibatnya. Contoh konkrit dari manfaat ICRC adalah ketika ICRC ada di Indonesia pada konflik Aceh, 
Jurnal Law Reform

Volume 13, Nomor 2, Tahun 2017
Program Studi Magister Ilmu Hukum Fakultas Hukum Universitas Diponegoro
Kalimantan, Ambon, dan Timor-Timur. ICRC membantu memenuhi kebutuhan dasar para pengungsi dan masyarakat yang menderita akibat konflik, bersama dengan Palang Merah Indonesia (PMI).

\section{ICRC Diakui oleh Masyarakat Internasional}

Pada awalnya pengakuan terhadap status ICRC didapat dari masyarakat internasional yang telah memahami benar bahwa tujuan dan fungsi yang diemban ICRC sangat penting dalam upaya memperlancar proses perdamaian dunia. Pengakuan masyarakat internasional ini dibuktikan melalui lahirnya Konvensi Jenewa tahun 1949 dan Protokol Tambahannya tahun 1977 sebagai hasil konferensi internasional.

Pengakuan negara terhadap status ICRC dikuatkan dalam Headquarter Agreement atau Seat Agreement antara ICTRC dengan negara dimana ia memiliki perwakilan. Dengan adanya perjanjian ini, maka negara tersebut mengakui dan menghormati kerja ICRC di seluruh wilayah negaranya dan tidak mencampuri prinsip-prinsip ICRC dalam menjalankan tugasnya. Headquarter Agreement ini contohnya yang dibuat antara ICRC dengan Swiss, tempat dimana ICRC menempatkan markas berkasnya (di Jenewa). Perjanjian ini ditandatangani tanggal 1993 dimana Swiss mengakui status ICRC sebagai subyek Hukum Internasional dan menegaskan kembali bahwa ICRC dalam menjalankan tugasnya bersifat independen dan terlepas dari pemerintah Swiss. Pengakuan negara juga dibuktikan dengan keikutsertaan negara-negara penandatanganan Konvensi Jenewa dalam Konferensi Internasional Palang Merah yang secara aktif dipersiapkan dan diikuti oleh ICRC, sejak Konferensi I di Paris tahun 1867 sampai Konferensi XXVI di Jenewa tahun 1995. Selain itu, negara-negara di hampir seluruh dunia mengizinkan ICRC melakukan aktivitas di dalam wilayahnya yang memerlukan bantuan kemanusiaan.

Pengakuan dari organisasi internasional, misalnya PBB, juga tidak kalah berartinya bagi eksistensi ICRC dalam hubungan antar bangsa. PBB sejak tanggal 16 Oktober 1990 berdasarkan Resolusi Majelis Umum No. 45/.6 dibawah judul "Observer status for the International Committee of The Red Cross, inconsideration of the special role and mandates conferred by the Geneva Conventions of 12 August 1949" memberikan status peninjau bagi ICRC dalam sidang-sidang Majelis Umum. Resolusi ini dibuat berdasarkan kesepakatan 138 negara anggota-anggota PBB. Dengan status ini, ICRC berkewajiban untuk hadir pada pertemuan-pertemuan dan konferensikonferensi berkala organ-organ utama PBB (antara lain Majelis Umum, Dewan Keamanan, Dewan Ekonomi dan Sosial). Dengan status sebagai peninjau ini, walaupun tidak memiliki hak suara, tetapi ICRC memiliki hak-hak istimewa, misalnya 
untuk memberikan pendapat atas inisiatif sendiri (tanpa diminta oleh organ-organ PBB). ${ }^{5}$ Pengakuan secara internasional terhadap ICRC ini tidak terjadi secara begitu saja. Sejak berdiri hingga saat ini tentu diperlukan kinerja yang konsisten dalam jangka waktu panjang dan perjuangan yang tidak mudah. Atas dasar itulah, kini ICRC memetik buah dari perjuangannya hingga diakui oleh negaranegara lain dan organisasi internasional lainnya.

\section{B. Peran ICRC dalam Perkembangan Hukum Humaniter Internasional}

Peran ICRC dalam pengembangan Hukum Humaniter Internasional pada dasarnya adalah memantau perubahan sifat konflik bersenjata, termasuk diantaranya adalah mengatur konsultasi dengan maksud untuk memastikan kemungkinan mencapai kesepakatan tentang aturan baru dan mempersiapkan rancangan teks untuk diserahkan kepada konferensi diplomatik. Contoh dari dua Protokol Tambahan Konvensi Jenewa memberikan gambaran bagaimana Hukum Humaniter Internasional dibuat serta kontribusi ICRC didalamnya, yaitu :

a). Berdasarkan aturan rancangan yang disiapkan pada tahun 1956, maka resolusi tersebut diadopsi pada tahun 1960 oleh dua Konferensi Internasional Palang Merah dan oleh

${ }^{5}$ ICRC, Offprints International Review of the Red Cross No. 279-280, Nov-Dec 1990 \& Jan-Feb 1991, Geneva, 1991, halaman 38.
International Human Rights Conference yang diselenggarakan di Teheran pada tahun 1968. Saat itu ICRC mempelajari kemungkinan melengkapi Konvensi diadopsi di 1949;

b) Pada tahun 1969 ICRC menyampaikan gagasan bahwa pada Konferensi Internasional ke-21 Palang Merah, di Istanbul; peserta, termasuk pihak Amerika pada Konvensi Jenewa, mandat itu sesuai dan pengacara ICRC sendiri memulai pekerjaan persiapan;

c) Antara tahun 1971 dan 1974, ICRC mengadakan beberapa konsultasi dengan pemerintah dan Gerakan; PBB secara teratur diberikan laporan kemajuan;

d) Tahun 1973 tanggal 22 Konferensi Internasional Palang Merah, di Teheran, dianggap draft teks dan didukung sepenuhnya pekerjaan yang dilakukan;

e) Pada bulan Pebruari 1974 Pemerintah Swiss, sebagai penyimpan Konvensi Jenewa 1949, menyelenggarakan Konferensi Diplomatik pada penegasan kembali dan perkembangan Hukum Humaniter Internasional yang berlaku dalam konflik bersenjata, di Jenewa; itu terdiri dari empat sesi dan berakhir pada bulan Juni 1977; pada sesi akhir Konferensi itu, 102 Artikel Protokol I dan 28 Artikel Protokol II diadopsi oleh berkuasa penuh 102 negara diwakili 
Jurnal Law Reform

Volume 13, Nomor 2, Tahun 2017
Program Studi Magister Ilmu Hukum Fakultas Hukum Universitas Diponegoro
1. Laporan Hukum Humaniter Internasional Kebiasaan Dari ICRC

Pada bulan Desember 1995, Konferensi Internasional Palang Merah dan Bulan Sabit Merah ke-26 secara resmi memberikan mandat kepada ICRC untuk menyusun sebuah laporan tentang aturan-aturan Hukum Humanier Internasional yang berasal dari Hukum Kebiasaan dan dapat berlaku dalam konflik bersenjata internasional maupun non internasional. Hampir 10 tahun kemudian, yaitu pada tahun 2006, seusai dilakukan penelitian yang ekstensif dan konsultasi yang meluas dengan para pakar, maka laporan ini, yang sekarang disebut sebagai Studi Hukum Humaniter Internasional Kebiasaan (Study on Customary International Humanitarian Law), diterbitkan. ${ }^{6}$

Tujuan dari dibuatnya Hukum Humaniter Internasional Kebiasaan ini ialah untuk mengatasi sebagian dari masalah-masalah yang berkaitan dengan penerapan Hukum Humaniter Internasional Perjanjian (misal, Konvensi Jenewa beserta Protokol Tambahannya). Setidaknya ada 2 hal pokok yang menghambat penerapan perjanjianperjanjian internasional tadi dalam berbagai konflik bersenjata yang berlangsung dewasa ini. Pertama, perjanjian internasional hanya berlaku bagi negaranegara yang telah meratifikasinya. Ini berarti bahwa

\footnotetext{
6 Jean-Marie Henckaerts dan Louise Doswald-Beck, Customary Internasional Humanitarian Law, 2 jilid, Jilid I, Rules (Aturan-aturan), Jilid II, Practice (Praktik) [2 Bagian], Cambridge University Press, 2005
}

dalam konflik bersenjata yang berlain-lainan berlaku perjanjian internasional yang berlain-lainan pula, tergantung pada perjanjian internasional manakah yang telah diratifikasi oleh negara-negara yang terlibat konflik. Kedua, banyak dari konflikkonflik bersenjata yang dewasa ini berlangsung adalah konflik bersenjata non internasional, dan konflik bersenjata jenis ini belum diatur secara cukup rinci oleh Hukum Humaniter Internasional Perjanjian. Hanya perjanjian internasional dalam jumlah terbatas saja yang berlaku dalam konflik bersenjata non internasional, yaitu Konvensi Senjata Konvenvional Tertentu sebagaimana telah diamandemen, Statuta Pengadilan Pidana Internasional, Konvensi Ottawa tentang Pelarangan Ranjau Darat Anti personil, Konvensi Senjata Kimia, Konvensi Den Haag tentang Perlindungan Benda Budaya, dan lain sebagainya.

\section{Peran ICRC Dalam Meningkatkan Pemahaman Hukum Humaniter Internasional}

Sebagai pionir atau perintis Hukum Perikemanusiaan Internasional, ICRC harus mendorong penghormatan terhadap hukum. ICRC melakukannya dengan menyebarkan pengetahuan tentang aturan kemanusiaan dan dengan mengingatkan pihak konflik kewajiban mereka.

a) Diseminasi dan Layanan Penasehat

Sejak ketidaktahuan hukum merupakan penghalang bagi pelaksanaannya, ICRC 
mengingatkan bahwa mereka telah dilakukan untuk membuat ketentuan kemanusiaan tersebut lebih dikenal. ICRC harus mengambil semua langkah yang diperlukan untuk memastikan bahwa hukum diterapkan secara efektif dan karena itu dihormati. Dalam hal ini ICRC melakukannya terutama melalui Penasihat pada Hukum Humaniter Internasional, yang menyediakan bimbingan teknis kepada negara dan membantu otoritas mereka mengadopsimya ke dalam ketentuan hukum dan perundangan nasional suatu negara.

b) Mengingatkan pihak dalam konflik kewajiban mereka

Terkait dengan perlindungan dan bantuan kemanusian dalam kinerjanya, ICRC membuat representasi rahasia kepada pihak yang berwenang dalam hal terjadi pelanggaran atas Hukum Humaniter Internasional. Dalam hal pelanggaran serius dan berulang terjadi, ICRC berhak untuk mengambil sikap publik; ia melakukannya hanya jika dianggap publisitas seperti berada di kepentingan orang yang terkena atau terancam. Ini karena itu tetap merupakan tindakan yang luar biasa.

Di samping itu ada sejumlah fungsi yang dilakukan ICRC sebagai pelaksana dan pengawal Hukum Humaniter Internasional, baik dalam situasi sengketa bersenjata internasional, non internasional, maupun pada masa damai, antara lain :7

\section{Monitoring}

Fungsi untuk secara terus menerus melakukan penilaian terhadap ketentuan-ketentuan Hukum Humaniter Internasional yang berlaku apakah masih sesuai atau relevan dengan kenyataankenyataan dan fenomena konflik bersenjata yang terjadi dewasa ini serta menyiapkan upaya penyesuaian atau adaptasi serta pengembangan terhadap ketentuan-ketentuan tersebut apabila dipandang perlu.

\section{Katalisator}

Menstimulus diskusi-diskusi yang berkaitan dengan permasalahan-permasalahan Hukum Humaniter Internasional dan mencari kemungkinan pemecahannya, khususnya dalam hal ini dengan kelompok ahli dari pemerintah. Diskusi-diskusi semacam ini dapat mengarah kepada suatu rekomendasi atas perubahan-perubahan terhadap hukum yang berlaku ataupun tidak. Fungsi ini berkaitan dengan fungsi pertama sebagaimana diuraikan di atas. Dalam hal ini, manakala suatu ketentuan misalnya dianggap sudah tidak relevan lagi dengan kenyataan yang ada, maka tidak cukup jika hanya mengatakan bahwa ketentuan tersebut

7 Arlina Permanasari, "Perlindungan Korban Konflik dan Proses menuju Perdamaian diAceh Perspektif Konvensi Jenewa 1949", Pusat Studi Hukum Humaniter Dan HAM, Fakultas Hukum Universitas TRISAKTI, Jakarta, 2003, halaman 14. 
Jurnal Law Reform

Volume 13, Nomor 2, Tahun 2017
Program Studi Magister Ilmu Hukum Fakultas Hukum Universitas Diponegoro perlu dirubah atau disesuaikan. Serangkaian tindakan perlu diambil termasuk untuk mendapatkan masukan dari ahli-ahli yang relevan dan berkaitan dengan permasalahan yang bersangkutan dan kemudian mendiskusikannya secara mendalam serta mencoba merumuskan kemungkinan pemecahannya.

\section{Promosi}

Meningkatkan pengetahuan dan pemahaman setiap orang akan ketentuan-ketentuan Hukum Humaniter Internasional sehingga harapan akan penerapannya pun akan menjadi lebih baik lagi. Tidak dapat dibayangkan bagaimana akan ada tindakan pelaksanaan apabila pemahaman atas isi dan maksud dari Konvensi Jenewa atau ketentuan Hukum Humaniter Internasional lainnya masih rendah. Karena itu disini dipilih kata "promosi" dan bukan hanya sekedar "disseminasi" atau penyebarluasan saja. Karena sasarannya tidak hanya agar ketentuan-ketentuannya diketahui dan dipahami, tetapi juga dilaksanakan serangkaian tindakan lanjutan, misalnya menerbitkan peraturan nasional sebagai pelaksanaan dari ketentuan Hukum Humaniter Internasional yang dimaksud.

\section{Melindungi}

Fungsi untuk melindungi Hukum Humaniter Internasional dari perkembangan-perkembangan hukum yang mengabaikan atau dapat melemahkan Hukum Humaniter Internasional itu sendiri. Hal ini bisa terjadi disebabkan ketidaktahuan atau kurangnya pemahaman perjanjian internasional lain selain Hukum Humaniter Internasional. Contoh mengenai hal ini adalah intervensi yang dilakukan oleh ICRC dan beberapa negara pada waktu penyusunan Pasal mengenai perlindungan anak pada waktu perang dalam Konvensi tentang HakHak Anak. Pada waktu itu ICRC dan beberapa negara tersebut melihat bahwa Pasal yang diusulkan tidak sesuai dengan apa yang tedapat didalam Konvensi Jenewa tahun 1949 dan Protokol Tambahannya tahun 1977.

\section{Melakukan Tindakan Nyata}

Melakukan tindakan konkrit dan memberikan kontribusi praktis bagi penerapan hukum dalam situasi konflik bersenjata. Fungsi ini adalah fungsi yang terpenting bagi ICRC, yakni melakukan tindakan-tindakan nyata dan konkrit bagi korbankorban sengketa bersenjata. Misalnya diatur bahwa pihak-pihak yang bersengketa harus memperhatikan hak-hak dari mereka yang terluka, sakit, meninggal atau ditawan karena terjadinya sengketa bersenjata. Dalam hal ini ICRC pertamatama mengingatkan para pihak yang bersengketa tentang kewajiban ini dan yang kedua memberikan bantuan secara langsung kepada korban-korban sengketa bersenjata tersebut.

\section{Pengawasan Atau Anjing Penjaga}

Mengingatkan negara-negara dan pihak-pihak lain yang terlibat dalam suatu sengketa bersenjata dan juga kepada masyarakat internasional secara 
Jurnal Law Reform

Volume 13, Nomor 2, Tahun 2017
Program Studi Magister Ilmu Hukum Fakultas Hukum Universitas Diponegoro keseluruhan manakala terjadi pelanggaranpelanggaran serius terhadap Hukum Humaniter Internasional. Fungsi ini digambarkan seperti membunyikan alarm manakala terjadi pelanggaranpelanggaran serius, namun dalam melakukannya, fungsi ICRC lebih mengutamakan kepada dialog secara langsung dan konfidensial dengan pihakpihak yang berkompeten, dimana pelanggaran serius tersebut terjadi. Hanya dalam situasi-situasi yang sangat spesifik dimana terlihat sama sekali adanya kehendak pihak yang bersengketa untuk menerapkan Hukum Humaniter Internasional, maka kemudian ICRC meminta perhatian masyarakat internasional. Contoh mengenai hal ini adalah kasus pembersihan etnis yang terjadi di bekas negara Yugoslavia.

\section{Kesimpulan}

Berdasarkan hasil pembahasan dalam penelitian tersebut, maka dapat ditarik suatu kesimpulan, sebagai berikut :

1. ICRC secara umum diakui sebagai organisasi internasional yang memiliki kedudukan sebagai subyek Hukum Internasional walaupun dengan ruang lingkup yang terbatas. Keanggotaan ICRC sendiri memang bukanlah terdiri dari negara-negara, tetapi sifat internasional ICRC sebagi sebuah organisasi tidaklah dilihat dari keanggotaannya, tetapi dari misi dan wilayah kerjanya yang berada hampir di seluruh dunia.
Globalisasi memang telah membawa ilmu pengetahuan dan teknologi berkembang menjadi begitu signifikan, tetapi pada kenyataannya kemajuan tersebut belum mampu membawa kedamaian di dunia. Setidaknya hingga detik ini masih ada beberapa konflik bersenjata terkait masalah keamanan (baik itu terorisme, perang saudara, atau perang antar negara) yang terjadi dan memakan korban dalam jumlah besar. Pada titik ini peran ICRC sebagai organisasi khusus masih memiliki peran krusial dalam hal perlindungan dan bantuan kemanusian terhadap korban perang. ICRC harus bekerja keras untuk memaksa para pihak yang bertikai untuk memperhatikan dan menerapkan Hukum Humaniter Internasional sebagai batasan mereka dalam melakukan tindakan-tindakan perang atau pun konflik bersenjata internasional maupun non internasional. Pada perkembangannya eksistensi dari ICRC bisa dibilang masih tidak tergantikan. $\mathrm{Hal}$ ini setidaknya dipengaruhi oleh 3 hal pokok yang menurut penulis memiliki pengaruh dalam eksistensi ICRC. Tiga hal tersebut adalah, selama masih ada perang, eksistensi ICRC akan selalu terjaga; belum ada organisasi lain yg menjadi competitor; dan ICRC telah diakui oleh Masyarakat Internasional, 
4. Peran ICRC dalam pengembangan hukum humaniter pada dasarnya adalah memantau perubahan sifat konflik bersenjata, termasuk diantaranya adalah mengatur konsultasi dengan maksud untuk memastikan kemungkinan mencapai kesepakatan tentang aturan baru dan mempersiapkan rancangan teks untuk diserahkan kepada konferensi diplomatik. ICRC juga telah menyusun sebuah laporan tentang aturan-aturan $\mathrm{HHI}$ yang berasal dari Hukum Kebiasaan dan dapat berlaku dalam konflik bersenjata internasional maupun non-internasional yang sekarang disebut sebagai Studi Hukum Humaniter Internasional Kebiasaan (Study on Customary International Humanitarian Law).

5. Sebagai promotor dan wali hukum kemanusiaan internasional, ICRC juga terus mendorong penghormatan terhadap hukum humaniter. ICRC melakukannya dengan menyebarkan pengetahuan tentang aturan kemanusiaan dan dengan mengingatkan pihak konflik kewajiban mereka. Kegiatan tersebut dilaksanakan dengan jalan diseminasi dan Layanan Penasehat, dan mengingatkan para pihak dalam konflik kewajiban mereka

\section{DAFTAR PUSTAKA}

Henckaerts, Jean-Marie dan Louise Doswald-Beck, 2005, Customary Internasional Humanitarian Law, 2 jilid, J ilid I, Rules (Aturan-aturan), Jilid II, Practice (Praktik) [2 Bagian], Cambridge University Press

ICRC, Offprints International Review of the Red Cross No. 279-280, Nov-Dec 1990 and JanFeb 1991, Geneva, 1991

Kusumaatmadja, Mochtar, dan Etty R. Agoes, 1997, Pengantar Hukum Internasional. Jakarta: Bina Cipta

Mc. Coubrey, Hilaire, 1994, International Humanitarian Law : The Regulation of Armed Conflicts

Moloeng, Lexy, 2002, Metodologi Penelitian Kualitatif, Bandung: PT Remaja Rosdakarya Permanasari, Arlina, dkk, 1999, Pengantar Hukum Humaniter, ICRC, Jakarta , 2003, "Perlindungan Korban Konflik dan Proses menuju Perdamaian di Aceh Perspektif Konvensi J enewa 1949", Pusat Studi Hukum Humaniter \& HAM, Fakultas Hukum Universitas TRISAKTI, Jakarta 